\title{
Setting the International Logistics Strategy: Empirical Investigation of Its Evolutionary Stages
}

\author{
Gino Marchet, Marco Melacini, Sara Perotti, and Elena Tappia* \\ Department of Management, Economics and Industrial Engineering, \\ Politecnico di Milano, Milano, Italy \\ \{gino.marchet, marco.melacini, sara.perotti, \\ elena.tappia\} apolimi.it
}

\begin{abstract}
A company may face the international challenge by tackling several issues, such as international sales and marketing, international sourcing, and foreign direct investments (FDI). The academic literature firstly focused on the reasons behind company internationalisation and then adopted the abovementioned issues related to the international challenge as perspectives in the investigation of the company internationalisation process. However, the literature review showed that the internationalisation process from a logistics perspective has not been fully investigated so far. Specifically, the relationship between company internationalisation choices and international logistics strategies has not adequately taken into account. This paper represents a first attempt to fill this gap by studying the relationship between the evolutionary stages of the company internationalisation and the key variables defining its international logistics strategy by providing empirical-based evidence.
\end{abstract}

Keywords: Sales Internationalisation, Logistics Strategy, Case Studies.

\section{Introduction}

A company may face the international challenge by tackling several issues such as international sales and marketing, international sourcing, and foreign direct investments (FDI). The academic literature firstly focused on the explanations of the reasons behind company internationalisation (e.g. [1]) and then used the abovementioned issues related to the international challenge as the perspectives to study the company internationalisation process. Previous contributions widely agree that the growth in the international trade implies that supply chains become more international and complex ([2]) and that logistics play a key role in such context $([3,4])$.

However, our analysis of the literature showed that the internationalisation process from a logistics perspective has not been fully investigated so far. Specifically, the relationship between company internationalisation choices (e.g. export via independent agents and creation of sales subsidiary) and international logistics strategies has not been in-depth examined. The different internationalisation choices

\footnotetext{
* Corresponding author.

B. Grabot et al. (Eds.): APMS 2014, Part I, IFIP AICT 438, pp. 50-58, 2014.

(C) IFIP International Federation for Information Processing 2014
} 
of a company have been widely studied in the literature (e.g. [5]), whereas the international logistics strategies have been examined by focusing only on specific topics, such as global supply chain planning centralisation (e.g. [6]), logistics strategies for entering new markets (e.g. [4]), and global supply strategies (e.g. [7]).

The above-mentioned issues represent a gap in the extant literature, as in company experience the international logistics strategy evolves and its evolution seems to be related to the stage in the company internationalisation process. This paper represents a first attempt to fill this gap by studying the relationship between the key variables defining the company international logistics strategies and internationalisation process by providing empirical-based evidence.

The remainder of the paper is organised as follows. The next section summarises the theoretical background. Afterwards, the research framework and methodology are reported, and findings are discussed. Finally, conclusions and limitations are drawn.

\section{$2 \quad$ Literature Review}

Coherently with the aim of this paper, the theoretical background is hereinafter discussed according to the two different issues involved, i.e. the company internationalisation process, and the company international logistics strategy.

\subsection{Internationalisation Process}

The entry modes into foreign markets can be classified into two main types, i.e. equity or non-equity. In the first case, the company acquires an existing local company or makes a green-field investment and has to decide whether partially or wholly own the local enterprise. In the second case, the company exports via agents and/or licensing. In the literature, the choice of the entry mode and the factors that impact on this decision has received a considerable attention and different theories have been developed to explain the reasons behind company internationalisation, such as the internalisation theory ([8]), the transaction cost theory ([1]), and the eclectic paradigm ([9]).

As far as the internationalisation process is concerned, the Uppsala model represents the most interesting contribution, especially considering the purpose of this study. Proposed by [5] and supported by several empirical studies (e.g. $[10,11,12])$, it is a behavioural and dynamic model that considers the internationalisation process as a sequence of incremental decisions. According to this model, all stages in the internationalisation process can be explained using the concepts of "State" and "Change" aspects. The "State Aspects" refer to the foreign market knowledge and commitment. The "Change Aspects" allowing to move along the stages of the internationalisation process lies in the commitment decisions that can strengthen the position in the foreign market and the learning from the experience of the current business activities. The Change and State Aspects affect each other, so that a stronger position in the market and better performance lead to a higher level of commitment and market knowledge. According to the Uppsala model and other contributions 
(e.g. [13]), four progressive stages can be selected by a company to sell products in foreign markets over time: no regular export activities, export via independent agents, creation of sales subsidiary, and production establishments.

\subsection{International Logistics Strategy}

The concept of "international logistics strategy" is widely used in the literature, but a detailed description of its related variables has not been developed so far. For the purpose of this study, we try to summarise as follows the main decisions involved in the definition of the company international logistics strategy that may be affected by the internationalisation choices.

The primary decision involved in the definition of the company international logistics strategies concerns the global supply chain network design that has a significant impact on the logistics performance (e.g. [14,15]). The design of the global supply chain networks refers to the number, location and capacities of warehouses and manufacturing plants, or the material flow through the logistics network (e.g. $[16,17])$.

Another key issue defining the international logistics strategy refers to the centralisation level in the global supply chain planning ([18]). Although planning is more critical to handle in case of inter-organisational supply chains, it represents a critical challenge also in internal supply chains ([19]). Moreover, it is particularly demanding for companies selling their products in different foreign markets when considering the planning of demand, inventory and transport ([18,20,21]). Previous contributions (e.g. [18]) also showed a strong correlation between the levels of internationalisation and centralisation of the supply chain planning process: the higher the internationalisation of production and procurement processes, the stronger the need for centralising the planning due to the increase of logistics complexity.

Also the planning of transport activities is part of the international logistics strategy and it is strictly connected with the company internationalisation choices, as they may be characterised by different pressures on lead times. The transport mode has been considered in numerous studies. For example, [22] and [23] considered three global transport service categories: airfreight, less than container load (LCL) shipping, and full container load (FCL) shipping. A more recent study by [17] evaluated different international logistics strategies mainly in terms of logistics network configuration and transport mode.

Finally, also the Incoterms (International Commercial Terms) contribute to describe the international logistics strategy, as they represent an indicator for the level of control on logistics flows. According to [24], a strategic advantage can be gained by a company willing to facilitate the sale of its products by assisting the importer in the shipment. Therefore, it can be assumed that the company interest in being involved in the shipment planning depends on the internationalisation choice.

\section{Research Framework and Questions}

The literature review showed that both the company internationalisation process and the related motivations have been widely studied. The stages along which a company 
may increase its international expansion can be considered well-defined, as well as the description of the dynamics for moving along the stages. At this regard, the Uppsala model seems to be the most consolidated. The key aspects explaining the evolution of the internationalisation process are the company commitment and learning over time, mostly related to the sales growth. Additionally, the evolution of the international logistics strategy, especially its relationship with the internationalisation process, has not been investigated so far. Specifically, there is no clear definition of the variables involved and, although a number of specific aspects have been addressed, they were studied separately from each other and independently from the internationalisation process. The literature review led us to develop the following research questions (also reported in Figure 1):

RQ1: What are the main variables involved in the definition of the company international logistics strategy that are related to their internationalisation choices? How are they related to the internationalisation choices?

RQ2: Is there a model for describing the evolution of the company international logistics strategy during the internationalisation process? Is the volume of the international sales the key variable of such model?

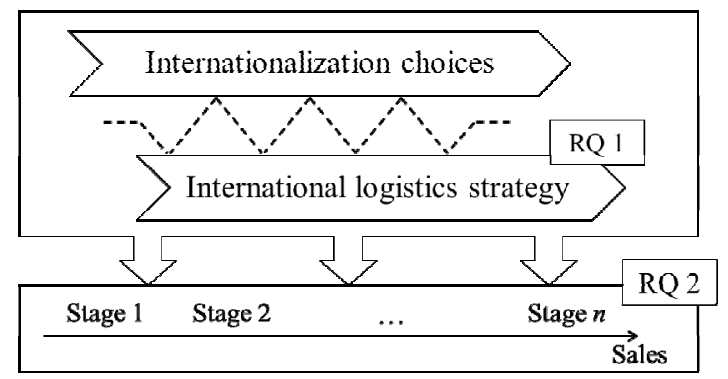

Fig. 1. Research framework

\section{Methodology}

In order to empirically investigate the designed research framework, the development of a series of case studies was considered as the most suitable methodology. In fact, the objective of the present research is to in-depth investigate how the variables involved in the definition of the international logistics strategy are affected by the company internationalisation choices ([25]). The companies included in the sample are big national or multi-national companies with plants concentrated in Europe. Additionally they export their finished goods in countries belonging to other continents with a make-to-stock production system. A deeper overview of the sample features is provided in Table 1. In line with the aim of the paper, the units of the analysis are represented by the single export areas of a company, so that multiple case studies were performed. Additionally, we used retrospective multiple case studies to collect longitudinal data on the evolution of the international logistics strategy during the different internationalisation stages that companies have experienced. Case studies 
were performed through semi-structured interviews with Logistics and Supply Chain Directors. General information about the company and the context in which it operates were also collected using secondary sources.

Table 1. Summary of the characteristics of the four companies of the sample

\begin{tabular}{|c|c|c|c|c|}
\hline Company & $\begin{array}{l}\text { Business } \\
\text { sector }\end{array}$ & $\begin{array}{l}\text { Annual group } \\
\text { sales }\end{array}$ & $\begin{array}{l}\text { Value to } \\
\text { weight ratio }\end{array}$ & Unit of analysis \\
\hline A & $\begin{array}{l}\text { Baby, health } \\
\text { \& beauty care }\end{array}$ & 1.5 billion $€$ & Medium & $\begin{array}{l}\text { A1: South America } \\
\text { A2: Asia-Pacific area } \\
\text { A3: Russia }\end{array}$ \\
\hline B & $\begin{array}{l}\text { Porcelain } \\
\text { stoneware }\end{array}$ & 0.5 billion $€$ & Low-medium & $\begin{array}{l}\text { B1: North America } \\
\text { B2: Israele }\end{array}$ \\
\hline $\mathrm{C}$ & $\begin{array}{l}\text { Medical } \\
\text { technology }\end{array}$ & 1.1 billion $€$ & Medium & $\begin{array}{l}\text { C1: Asia-Pacific area } \\
\text { C2: Russia }\end{array}$ \\
\hline $\mathrm{D}$ & $\begin{array}{l}\text { Sanitary } \\
\text { technology }\end{array}$ & 1.8 billion $€$ & Low-medium & $\begin{array}{l}\text { D1: Pacific area } \\
\text { D2: South America }\end{array}$ \\
\hline
\end{tabular}

As far as the internationalisation process evolution is concerned, we defined three levels, based also on the stages identified by the extant literature: (i) early stage, i.e. export via independent agents or distributors, (ii) intermediate stage, i.e. export via sales subsidiary, and (iii) advanced stage, i.e. export via company own stores. To assess the company international logistics strategy, we gathered information on the variables highlighted in the literature review: (i) network design, (ii) centralisation level in the distribution planning, (iii) governance of the transport planning, and (iv) level of control on logistics flows.

\section{$5 \quad$ Discussion and Findings}

\subsection{Variables Defining the Company International Logistics Strategy}

Network Design. All companies have confirmed that the decisions on the supply chain network design are much related to the internationalisation choices. According to the information collected through the case studies, the types of decisions mainly refer to the selection among direct shipment, 1-echelon networks and 2-echelon networks. In fact, a company can sell its products without having local distribution centres (as in the B2 case in which there are monthly shipments to distributors) or, on the contrary, it can be decided whether it is necessary to have stocks near its point of sales based for instance on the lead-time constraints (as in the $\mathrm{C} 1$ case). The adoption of a 2-echelon network has been observed in case of logistics networks delivering products in different countries of the same continental area (as in the A1 case).

Centralisation Level in the Distribution Planning. In line with the extant literature, the level of distribution planning centralisation is a key aspect to manage when defining the logistics strategy of global supply chains. The following aspects are those mainly involved in such process with reference to each export area: sale forecasts, inventory management, service level to the customers, and transport planning. 
The distribution planning can be decentralised (as in the B1 case), i.e. only some decisions made by the subsidiaries are shared with the headquarter (e.g. the maximum stock levels and service levels that have to be provided by the logistics service providers), or centralised (as in the A1 case), i.e. the subsidiaries are not autonomous. Besides, as for example in the company $\mathrm{C}$ case, the distribution planning can be coordinated, i.e. the company develops the sale forecasts together with the independent agents but is not involved in managing the logistics process as it does not have an own network in the export area.

Governance of the Transport Planning. In line with the literature, the transport planning is a variable of the international logistics strategy and the related decision process varies according to the company internationalisation choices. When a company exports via independent agents, the governance of the transport planning is "low" as the transport organisation depends only on the lead times and order quantities required by the customers (e.g. in the D2 case). Instead, when a company exports via sales subsidiary and its logistics network is more complex (e.g. a local warehouse delivers goods to the sales subsidiary), the governance of the transport planning is "high" (e.g. in the C1 case). In this case, the company has to manage the delivery of goods to the warehouse and has the possibility to optimise the transport activity (e.g. use of sea instead of air freight or use of FCL service).

Level of Control on Logistics Flows. According to the information collected through case studies, the Incoterms can be viewed as an indicator of the level of company control on the logistics and transport process to the foreign market and strictly related with the internationalisation choices, although quite disregarded by past literature on the logistics process in global supply chains. The case study analysis shows that companies exporting via independent agents (e.g. D2 case) or subsidiaries (e.g. C1 case) select Incoterms E and F. In fact, in this case the company sells its products to the agents and it not interested in managing the transport and logistics process. Instead, a company that a company selling its products via company own stores manages the distribution process and uses Incoterms C and D (e.g. A1 case).

Three international logistics strategies have been identified based on the values assumed by each variable and the correlation among them (Table 2): (i) International sale, (ii) International outpost, and (iii) International network.

Table 2. International logistics strategies from the case studies

\begin{tabular}{|c|c|c|c|c|}
\hline & & \multirow{2}{*}{\multicolumn{3}{|c|}{ International logistics strategies }} \\
\hline & & & & \\
\hline & & $\begin{array}{l}\text { International } \\
\text { sale }\end{array}$ & $\begin{array}{l}\text { International } \\
\text { outpost }\end{array}$ & $\begin{array}{l}\text { International } \\
\text { network }\end{array}$ \\
\hline \multirow{4}{*}{$\begin{array}{l}\text { Dimension } \\
\text { of the } \\
\text { international } \\
\text { logistics } \\
\text { strategy }\end{array}$} & Network design & $\begin{array}{l}\text { Not } \\
\text { significant }\end{array}$ & $\begin{array}{l}\text { 1-echelon } \\
\text { network }\end{array}$ & $\begin{array}{l}\text { 2-echelon } \\
\text { network }\end{array}$ \\
\hline & $\begin{array}{l}\text { Centralisation level in } \\
\text { the distribution planning }\end{array}$ & Coordinated & Decentralised & Centralised \\
\hline & $\begin{array}{l}\text { Governance of the } \\
\text { transport planning }\end{array}$ & $\begin{array}{l}\text { Not } \\
\text { significant }\end{array}$ & Medium & High \\
\hline & $\begin{array}{l}\text { Level of control on } \\
\text { logistics flows }\end{array}$ & Low & Medium & High \\
\hline
\end{tabular}




\subsection{Evolution of the Company International Logistics Strategy during the Internationalisation Process}

The case study analysis provides evidence supporting the relationship between the company international logistics strategy and its internationalisation choices. As shown in Table 3, the International sale strategy is more likely to be selected by companies in the early stage of the internationalisation process evolution, the International outpost by companies in the intermediate stage, and the International network by companies in the advanced stage. Additionally, for a given export area the evolution of the international logistics strategy incrementally evolves together with the internationalisation process as the sales and the learning in the foreign market growth.

Table 3. Alignment between internationalisation process and international logistics strategies

\begin{tabular}{|c|c|c|c|c|}
\hline $\begin{array}{l}\text { International } \\
\text { logistics } \\
\text { strategies }\end{array}$ & $\begin{array}{l}\text { International } \\
\text { network } \\
\text { International } \\
\text { outpost } \\
\text { International } \\
\text { sale } \\
\end{array}$ & \multicolumn{3}{|c|}{$\begin{array}{l}\mathrm{A} 1 ; \mathrm{A} 2 ; \mathrm{A} 3 ; \mathrm{B} 1 ; \\
\mathrm{C} 1 ; \mathrm{D} 2\end{array}$} \\
\hline & & Early stage & Intermediate stage & Advanced stage \\
\hline & & \multicolumn{3}{|c|}{ ationalisation process stages } \\
\hline
\end{tabular}

When a company is in the early stage of the internationalisation process, its export volume is typically low as well as its market knowledge. As a consequence, it operates in a foreign market with a low level of control on the logistics and transport process, which is a key feature of the International sale strategy. According to the case study analysis, at this stage, the choice of exporting via independent agents (as in the D2 case) or distributors (as in the D1 case) allows the company to not have own resources, and therefore sunk costs, that are implied instead when it has subsidiaries or store networks. Additionally, the benefits related to have no local warehouses and to overcome complexities (e.g. to face the local regulations and to collaborate with local logistics providers) have been cited by companies of the sample as other benefits of selecting the International sale strategy in the early stage of the internationalisation process. Such approach for entering a new market has been adopted in all cases except for the A1 case in which the company opened a subsidiary when starting to sell its products in the new market.

Looking at the sample, companies A, B and C developed their logistics strategy from the International sale to the International outpost when they started to export via sales subsidiary (i.e. the intermediate stage of their internationalisation process) in South America, North America and Asia-Pacific, respectively. They report the increasing in sales and market experience as enabling factors to develop the second stage of the internationalisation process and the international logistics strategy. The transition to this second stage can occur through the acquisition of the local distributor by the company (as in the A3 case). At this stage, the companies let the subsidiaries 
work autonomously in developing the sale forecasts, defining the order quantities (i.e. decentralised planning), and also managing the transport and logistics process (i.e. adoption of Incoterms $\mathrm{E}$ or F). The local logistics network is composed of one distribution centre (i.e. 1-echelon network) that receives FCLs.

In the examined sample, no companies have already developed the International network strategy. Only company A is evaluating the adoption of such approach in South America where the advanced stage of the internationalisation process has been reached by selling its products via own stores. It intends to build a 2-echelon logistics network composed of a central distribution centre for the entire export area and other regional depots in each country belonging to the area. This approach seems to imply a more centralised planning and control on the transport process.

It should be noted that a company has not necessarily to go through all the stages. For instance, a company can directly go to the intermediate stage by adopting the International outpost as logistics strategy without exporting via independent agents or distributors before this settlement (as in the A1 case).

\section{Conclusion}

This paper explores the relationship between company international logistics strategy and its internationalisation process through case study methodology. Findings suggest that companies progressively develop their international logistics strategy based on the stage of their internationalisation process. Three international logistics strategies have been identified, that diverge in terms of network design, level of centralisation in the distribution planning, governance of the transport planning, and level of control on logistics flows. The International sale strategy is more likely to be chosen by companies in the early stage, the International outpost by those in the intermediate stage, whereas the International network by those in the advanced stage. Although interesting, the conclusions drawn require further effort to be more generalised. Other case studies are recommended with the aim of i) verifying whether the variables considered are comprehensive and consistent, and ii) further exploring the variables driving the evolution of the logistics strategy. Finally, additional effort should be devoted to the development of a normative model supporting companies in aligning the international logistics strategy with their plans in term of internationalisation.

\section{References}

1. Hennart, J.-F.: A Theory of Multinational Enterprise. University of Michigan Press, Ann Arbor (1982)

2. Monczka, M., Trent, J.: Achieving Excellence in Global Sourcing. Sloan Manage Rev. 47(1), 24-32 (2006)

3. Peterson, K.J., Frayer, D.J., Scannel, T.V.: An Empirical Investigation of Global Sourcing Strategy Effectiveness. J of Supply Chain Manage 36(2), 29-38 (2000)

4. Straube, F., Ma, S., Bohn, M.: Internationalisation of Logistics Systems - How Chinese and German Companies Enter New Markets. Springer, Heidelberg (2008) 
5. Johanson, J., Vahlne, J.E.: The Internationalisation Process of the Company - A Model of Knowledge Development and Increasing Foreign Market Commitments. J. Int. Business Stud. 8(1), 305-322 (1977)

6. Jonsson, P., Rudberg, M., Holmberg, S.: Centralised Supply Chain Planning at IKEA. Supply Chain Manage Int. J. 18(3), 337-350 (2013)

7. Loppacher, J.S., Cagliano, R., Spina, G.: Key Factors in Global Supply Headquarterssubsidiary Control Systems. J. Manuf. Technol. Manage. 21(7), 794-817 (2010)

8. Buckley, P.J., Casson, M.: The Future of the Multinational Enterprise. Holmes \& Meier, New York (1976)

9. Dunning, J.H.: Toward an Eclectic Theory of International Production: Some Empirical Tests. J. Int. Business Stud. 11(1), 9-31 (1980)

10. Barkema, H.G., Bell, H.J., Pennings, J.M.: Foreign Entry, Cultural Barriers, and Learning. Strategic Manage J. 17(2), 151-166 (1996)

11. Bello, D.C., Barksdale, H.C.: Exporting at Industrial Trade Shows. Ind. Market Manag 15(3), 197-206 (1986)

12. Luo, Y., Peng, M.: Learning to Compete in a Transition Economy: Experience, Environment and Performance. J. Int. Business Stud. 30(2), 269-295 (1999)

13. Johanson, J., Wiedersheim-Paul, F.: The Internationalization of the Company: Four Swedish Cases. J. Man. Studies 12(3), 305-322 (1975)

14. Sezen, B.: Relative Effect of Design, Integration and Information Sharing on Supply Chain Performance. Supply Chain Manage. Int. J. 13(3), 233-240 (2008)

15. Pero, M., Rossi, T., Noé, C., Sianesi, A.: An Exploratory Study of the Relation Between Supply Chain Topological Features and Supply Chain Performance. Int. J. Prod. Econ. 123(2), 266-278 (2010)

16. Chopra, S., Meindl, P.: Supply Chain Management: Strategy, Planning and Operations. Prentice Hall, Upper Saddle River (2004)

17. Creazza, A., Dallari, F., Melacini, M.: Evaluating Logistics Network Configurations for a Global Supply Chain. Supply Chain Manage Int. J. 15(2), 154-164 (2010)

18. Melacini, M., Creazza, A., Perotti, S.: Analysis of Supply Chain Planning Centralisation for Multinational Companies. Int. J. Logistics Systems Manage 9(4), 478-500 (2011)

19. Forget, P., D’Amours, S., Frayret, J.M.: Multi-behavior Agent Model for Planning in Supply Chains: An Application to the Lumber Industry. Robot Cim-Int. Manuf. 24(5), 664-679 (2008)

20. Pirttila, T., Niemi, P.: Generic Organizational Choices for Logistics in Decentralized Organizations: Implications for inventory management. Int. J. Prod. Econ. 45(3), 195-202 (1996)

21. Rudberg, M., West, B.M.: Global Operations Strategy: Coordinating Manufacturing Networks. Omega: Int. J. Manag. Sci. 36(1), 91-106 (2008)

22. Zeng, Z.: Global Sourcing: Process and Design for Efficient Management. Supply Chain Manage Int. J. 8(4), 367-379 (2003)

23. Colicchia, C., Dallari, F., Melacini, M.: Increasing supply chain resilience in a global sourcing context. Prod Plan Control 21(7), 680-694 (2010)

24. David, P.A., Stewart, R.D.: International Logistics: the Management of International Trade Operations. Cengage Learning (2010)

25. Eisenhardt, K.M.: Building Theories from Case Study Research. Acad. Manage Rev. 14(4), 532-550 (1989) 